\title{
Raise the dikes and re-use the past? Climate adaptation planning as heritage practice
}

\author{
Linde Egberts $^{1}$ (I) $\cdot$ Svava Riesto $^{2}$
}

Received: 15 October 2020 / Accepted: 31 May 2021 / Published online: 17 September 2021

(C) The Author(s) 2021

\begin{abstract}
Across Europe, coasts are drastically being changed to adapt to relative sea level rise, which will influence coastal landscapes and heritage in many ways. In this paper, we introduce a methodological starting point for analysing the ways in which landscape architects and spatial planners engage with coastal landscapes and coastal heritage in the context of current climate adaptation projects. We test these methodologies by applying them to the Marconi dike strengthening project in Delfzijl, the Netherlands. This city's dike fortification is an interesting case, as it offers many opportunities for re-designing heritage. The city borders the Wadden Sea area, a tidal mudflat area protected as a UNESCO World Heritage Site for its natural and geological heritage values. The area also consists of a rich cultural landscape, which is overlooked in the public image and in local policy. We conclude that landscape architects and planners should strengthen not only the dike, but also the interpretation of the past that dominates policy and political debates in the area. We also find that the existing heritage production model of Ashworth and Tunbridge can provide some useful structure for understanding and contextualizing spatial planning for climate change as a way of doing heritage.
\end{abstract}

Keywords Methodology $\cdot$ Climate adaptation $\cdot$ Landscape architecture $\cdot$ Spatial planning $\cdot$ Natural heritage $\cdot$ Cultural heritage

\section{Introduction}

Over the past decades, designing landscapes with heritage has become an increasingly popular strategy among architects. Fueled by the inspirational experiences from the Ruhr area-particularly the Internationale Bauaustellung Emscherpark (1989-1999) - landscape architects are engaging more and more with heritage objects, structures, and values (Riesto and Tietjen 2018). This comes as no surprise, as cultural heritage has shifted from being a separate sector in society, run by experts and focused on the conservation of individual buildings, to a vector in which many stakeholders re-use and transform spatial heritage to make and shape the living environments of the future (Janssen et al. 2017). This intertwinement of heritage and spatial planning is closely

Linde Egberts

1.r.egberts@vu.nl

Svava Riesto

svri@ign.ku.dk

1 Vrije Universiteit Amsterdam, Amsterdam, the Netherlands

2 University of Copenhagen, Copenhagen, Denmark related to the idea that heritage can be used as a resource to achieve certain local development goals, such as making places attractive to residents and tourists, strengthening people's attachment to places, and branding and promoting places (Holtorf and Fairclough 2013). This implies that the selection, preservation, and development of heritage is no longer limited to experts and policy makers but has become part of a much broader field of practices that directly or indirectly shape heritage.

With awareness of the effects of climate change on cities and landscapes growing, spatial planners and landscape architects have joined politicians and have taken on new tasks. Climate change has become a major priority, not only on political agendas, but also in the practice of spatial planners and landscape architects. Designing adaptation interventions that make landscapes more resilient to effects of climatic change such as drought, heavy precipitation, and flooding is currently a daily activity for many landscape architects, urbanists, and planners. ${ }^{1}$ Oftentimes, these measures have high political urgency and require drastic, large-scale interventions. This raises the question as to how these climate-related

\footnotetext{
${ }^{1}$ This also applies to mitigation measures, such as solar fields and wind parks, but these fall outside the scope of this article.
} 
measures engage with historic landscapes and heritage values, and to which extent these landscapes and values are taken into account.

In this article, we focus on how planners and landscape architects deal with the past when they design climate adaptation measures, approaching landscape planning processes as heritage practices. We do so from a critical heritage perspective, meaning that we aim to make explicit which traces of the past are regarded as heritage and, consequently, which are not. How are these traces appropriated in new design contexts? By doing this, we aim to develop methodological starting points for analysing landscape architecture and spatial planning processes and to relate climate adaptation to a much-needed discussion about values and priorities in heritage making.

We develop these methodological starting points by exploring one specific case study, namely the Marconi plan of the city of Delfzijl in the Dutch Wadden Sea area, which involves strengthening the city's sea dike (see Fig. 1). This case study has a twofold outcome: first, it helps us gain insight into the way in which heritage is appropriated in this particular planning process for climate adaptation. Secondly, it allows us to reflect on conceptual issues regarding our methodological starting points. This, in turn, will enable us to revise and improve these methodologies so that we can take up a broader set of case studies in the future.
By offering insight into the role of heritage in planning and landscape design from a critical and methodological perspective, we aim to stimulate practitioners to reflect critically on how they integrate the past into their spatial planning and design work. This could potentially inspire them to aim for diversity and richness and avoid pitfalls of recreating exclusive and oversimplified representations of the past.

\section{Landscape architecture and spatial planning as heritage: concepts and practices}

Heritage is more than the objects and places that have been handed down through past generations. It also includes processes of valuation, selection, and appropriation that decide and legitimize which parts of the past are remembered and commemorated. These processes also include processes of forgetting and acts of deliberate destruction to favour or deliberately endorse desired interpretations of the past over others (Smith 2006).

Against this backdrop, academics in the emergent field of heritage studies have argued that these processes of selection and appropriation are strongly tied to interpretations of the past that are favoured by the nation state. "Heritage is what contemporary society chooses to inherit and to pass on" (Tunbridge and Ashworth 1996). This so-called Authorized

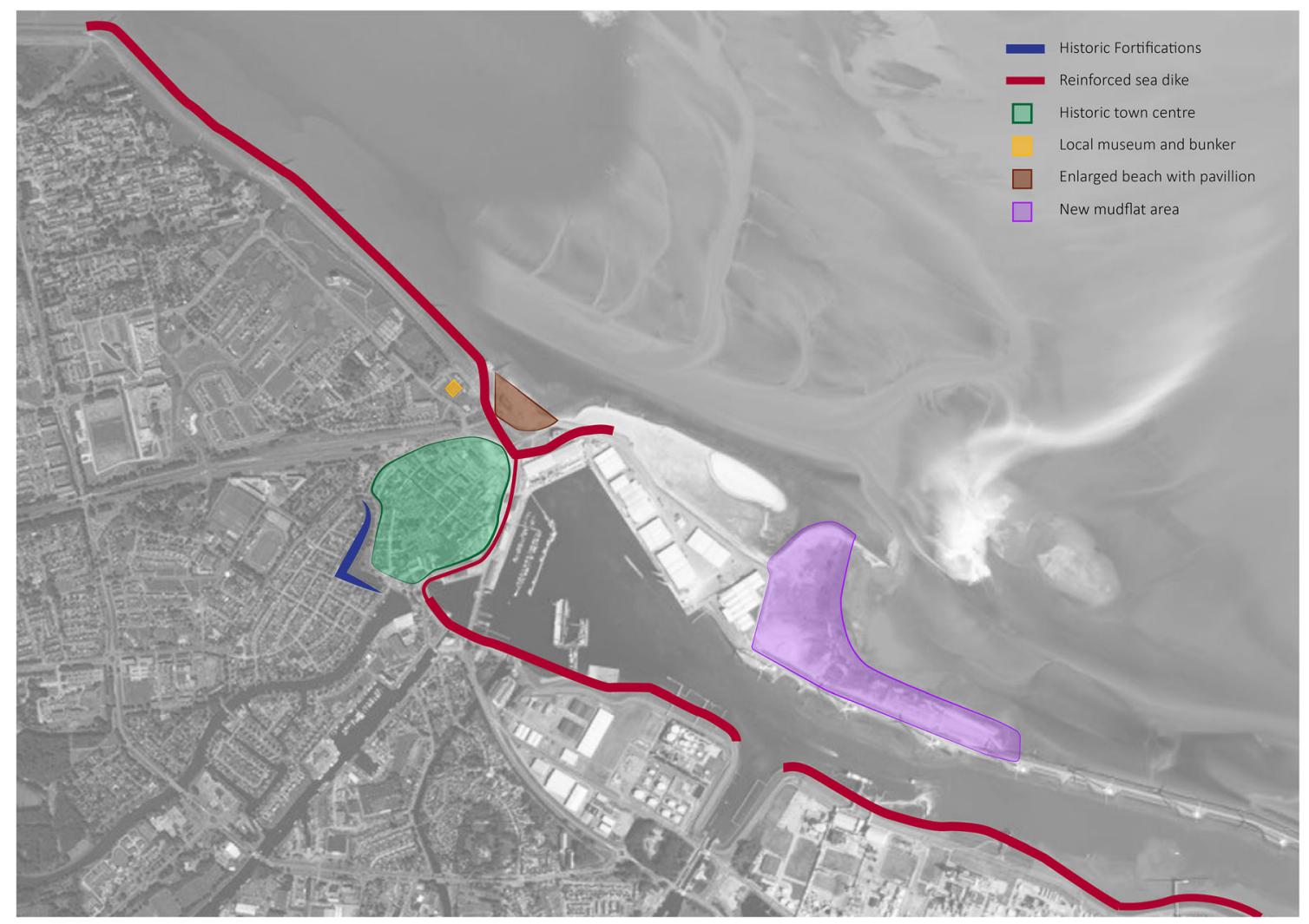

Fig. 1 Map of Delfzijl, showing the geographical situation of the heightened dike and heritage structures. Made by Marilena Mela, using Google Earth as a basis 
Heritage Discourse is repeated and legitimized by the institutional heritage world, in which heritage experts define what does and does not belong to "our" heritage. In this process, other interpretations of the past are excluded from the heritage canon and not represented in national historiography (Smith 2006). This is why heritage is always contested and dissonant, no matter what aims and values it is based on. Gregory Ashworth and Ian Tunbridge, key figures in the early formation of the field of critical heritage studies, put this process of heritage "production" in a model. They did so in the context of their study of World Heritage Sites and the ways in which commodification by tourism shaped the meanings and representations of these places (see Fig. 2).

In the process of doing heritage, landscapes play a key role, as they materialize and "naturalize" ideas of national identity. In a way, the verb "naturalize" refers to the socio-cultural constructs that nations are made of (Palmer 2002). In this context, landscapes can carry two distinctive, archetypical roles. The first one is the pastoral, which is deeply rooted in European romantic imagery of the landscape as a pre-industrial, nostalgic and bucolic place. The second role that landscapes can play is that of "wilderness" that often is preserved in natural heritage reserves. Following this idea, nature is seen as opposite to the cultural, which means that human presence and interference (past or present) should be minimized for the sake of protection of the "natural" (Egberts and Hundstad 2019; Spirn 1997).

Changes in the landscape always include implicit or explicit decisions about the past. Therefore, landscape architects and spatial planners engage with their projects in doing heritage, as they are key actors in deciding what is kept from the past and what is altered in current and future landscapes (Riesto and Tietjen 2018). Landscape architecture has always largely been determined by the ways in which new designs respond to existing environments Dixon Hunt John (2014). Since the 1980 s, heritage objects, structures, and stories have

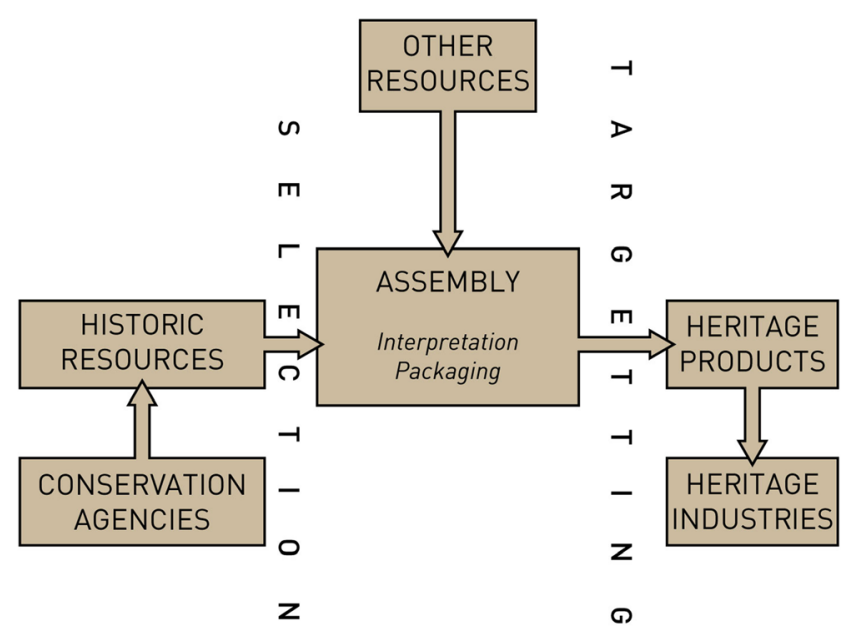

Fig. 2 Heritage production process by Tunbridge and Ashworth (1996) increasingly been used as resources for design, not in the least because of the gradual shift from a focus on urban expansion to regeneration and adaptive re-use (Braae 2015; Riesto and Tietjen 2018). During this period, heritage has grown from a separate sector dedicated to preserving heritage objects into an integrated factor in spatial planning, at least in many Western countries. From a conceptual point of view, this shift is characterized by moving from the preservation of material remains against change, to enhancing heritage values through change, in which heritage can represent a source of inspiration or an anchor for identification (Janssen et al. 2017). The selection, appropriation, forgetting, and demolition of the past that we mentioned in the context of national heritage also play a role in landscape architecture and spatial planning. The process of designing with heritage thus implies dissonance, as a selection has to be made in terms of which particular interpretations of the past are favoured over others.

The landscapes that take shape through spatial planning, landscape architecture, and the heritage decisions involved are not absolute entities. Rather, they should be perceived as "products of a myriad of interrelations" Harvey $(2015, b)$. The heritage narratives that are involved in shaping these landscapes are selected and adapted from earlier discourses resulting from previous interactional processes of actors with heritage narratives. In that sense, not only the places we study but also the heritage narratives involved can only be understood from a relational perspective Harvey $(2015$, b). This means that what is heritage in one context, does not necessarily be heritage in another, its meanings and categories change in relationship to various contexts and actors. Heritage can be shaped by different narratives in the context of climate adaptation measures can be something else than in other situations, such as a national programme for evaluating the heritage value of postwar architecture.

Currently, drastic changes are being made to landscapes worldwide in order to adapt them to climate change. Many heritage experts predominantly view climate change as a threat to cultural heritage (Fatoric and Seekamp 2017). Others argue, however, that this protectionist approach reduces heritage to a reified separate sector in which heritage is undertaken for the sake of preservation instead of relating it contextually. They would rather see that cultural heritage is used instrumentally to make societies more resilient to climate change. In the Dutch historic fishing town of Katwijk aan Zee, for example, a new dike was developed between the town and the sea, potentially creating a barrier that would destroy the town's visual relationship with the sea, which is at the core of the local heritage narrative. By involving the local population very early on in the process and taking their heritage values into account, the group of stakeholders was able to design a dike within a dune that is low enough to preserve the town's visual relationship with the sea (Bouland 2020). Some scholars argue that communities need creative engagements 
with the past - rather than material preservation - in order to live with climate change today and in the future (Harvey 2015, b; Holtorf 2018). A local response to the tsunami disaster of 2004 in Banda Aceh, Indonesia, can serve as an example here. The tsunami waves destroyed almost everything they hit, but also carried a fishing boat inland, which landed on top of a house. This boat became a symbol of the local community's resilience and replaced older heritage narratives, based on religion and colonialism, which had previously divided the community (Rico 2016)

\section{Developing methodologies}

Scholars in the field of heritage studies lean heavily on methodologies from adjacent academic fields, such as sociology, anthropology, and geography. Some valuable work has been undertaken to connect heritage concepts to methodologies, for example, in the context of the heritagescape (Garden 2006) and the biography of landscape (Roymans et al. 2009). However, most of these approaches are bound to specific domains of knowledge and often subdivide climate adaptation or heritage management into separate fields. Thus, methodological starting points for analysing landscape planning and design as heritage practices are scarce (Freestone et al. 2008).

To develop such a methodology, we take the heritage production model developed by geographers John E. Tunbridge and Gregory J. Ashworth as a starting point (Fig. 2). This model describes the process through which heritage is constructed, or produced or assembled. Tunbridge and Ashworth draw an analogy to industrial production processes, in which resources are used to produce commodities that are ready for consumption. They point out that in processes of heritage production (in world heritage sites or, as in our case, in spatial planning), the past is approached selectively as a potential resource. Before this selection process, there is a phase in which the "raw materials" are often deliberately chosen from a large "quarry of the past" (Tunbridge and Ashworth 1996, p. 7). The selected elements from the past are then interpreted or packaged by deliberately mixing them with other resources to create a heritage product. On the one hand, this quarry is limited, as material remains of the past, in particular, are irreplaceable. On the other hand, however, it is inexhaustible and always open for new interpretations of the old (Graham et al. 2000). The quarry of the past, then, does not only contain primary resources for re-interpretation, but also past interpretations of the past that represent what previous generations considered heritage. These are often re-used over and over again, shaping a heritage canon that predominates over other, less popular interpretations of the past (Egberts 2015). As such, the quarry of the past should not be imagined as a stable place made of solid rock, but rather as a fluid context of relations Harvey $(2015, b)$.

\section{Case study approach}

In this article, we apply the heritage production model of Ashworth and Tunbridge (1997) to one specific climate adaptation project in order to reflect on its applicability to and potential for international knowledge exchange across various case studies in the future. This enables us to disentangle the process of appropriation of the past in the context of landscape planning and design, and to study the outcomes. Riesto and Tietjen (2018) have already demonstrated that this model can be used to understand spatial design as a form of doing heritage. Ashworth and Tunbridge emphasize that their heritage production often applies to the ideas and feelings about heritage, not historical artifacts or sites. In our case, however, we would like to extend the model to include tangible aspects of heritage as well, as physical interventions in the landscape are an integral part of landscape planning and design in the context of heritage practices.

We chose the recently completed spatial development plan for the city centre and coastline of Delfzijl for this purpose, as it is an example of a recent climate adaptation plan that covers both the land and the seaside of the city's coastal area. This "Marconi Plan" (an abbreviation for maritime concepts in $\operatorname{sigh} t^{2}$ ) is a particularly interesting case, because the sea dike marks the boundary of the Wadden Sea UNESCO World Heritage Site (Fig. 3). This means that the area outside the dike is protected by national policy and is internationally recognized for its natural heritage values. The dike itself forms a sharp division between a "natural landscape" and a "cultural landscape" that needs protection against nature's potentially threatening tides (Egberts 2019).

The city of Delfzijl has a rich history and is part of a unique cultural landscape, according to cultural heritage experts, geographers, and archaeologists alike Egberts (2019). Relative sea level rise is one of the main challenges in the area, in addition to a shrinking population, resulting in empty shops and giving the historic city centre a rundown feel (Delfzijl 2013). An increase in tourism could potentially bring the area's population decline to a halt (Veldman 2020), and just as other places along the Dutch Wadden Sea coast, including Harlingen and Holwerd, Delfzijl smartly combines climate adaptation projects, and the large national investments that come with them, with other measures. In this case, the municipality has aimed to increase the livability of the city centre and has tried to make the area more appealing for tourists including camping enthusiasts, cyclists, hikers, and recreational sailors (Delfzijl 2009). The municipality believes that the vicinity of the Wadden Sea World Heritage Site is an excellent opportunity to make Delfzijl an access point for anyone looking to explore nature (Veldman 2020).

\footnotetext{
${ }^{2}$ All quotations from the planning documents and interviews were translated from Dutch to English by the first author.
} 


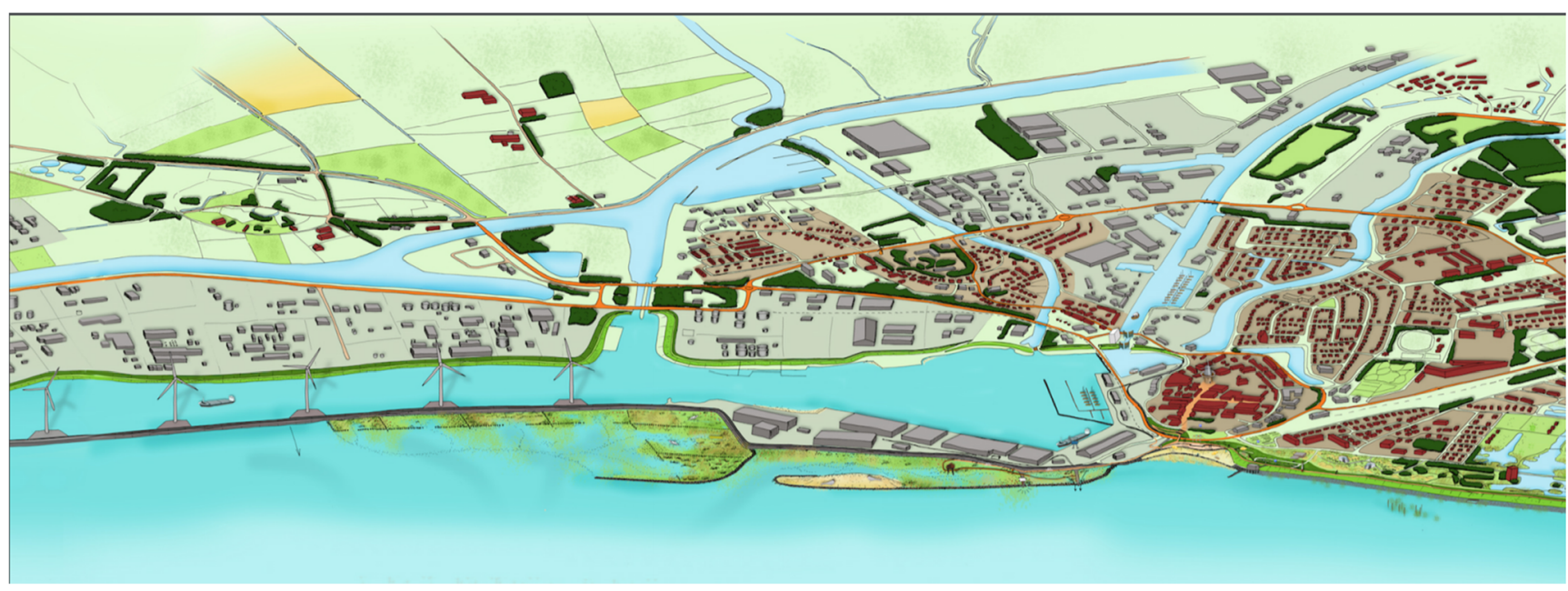

Fig. 3 Impression of Marconi, as produced by Delfzijl municipality. By taking a bird's eye perspective from the sea and choosing a hand-drawn style, the maker of this image taps into a centuries' old tradition of depicting port cities, as was done by Anthonisz. In his view of
Amsterdam, dating from 1538. Waterfront Delfzij1 - Waarom Marconi. https://www.delfzijl.nl/waterfront-delfzijl-marconi/ (accessed July 10, 2020)

2017 in the analysis, because many practical and design decisions were taken that touch upon these more detailed plans. In these designs and drawings, it became apparent how the plan was translated into concrete interventions in the landscape.

Secondly, we conducted two interviews with the project and process managers to gain a better understanding of the context of the project, which also deepened our insight into the documents we had collected. This way, we learned more about stakeholder involvement and gained information about why certain aspects of heritage were highlighted while others were neglected. Finally, we made site visits in 2019 and 2020 to observe and visually document the realization of the ongoing project in the landscape by taking photographs, which form a visual underpinning of the observations we also describe in words.

\section{Case study Marconi plan in Delfzijl}

\section{The planning process and its actors}

The Marconi project was initiated by the municipality of Delfzijl, which was confronted with the first scenarios of sea level rise around 2007. The most straightforward response to sea level rise was to raise the existing steel dam wall around the centre, but the municipality feared that this would jeopardize all previous efforts to make Delfzijl more livable (Veldman 2020). To prevent this from happening, the municipality started an alliance with two water boards, a neighbouring municipality, the national Department of Waterways and Public Works (Rijkswaterstaat), the province of Groningen, the regional landscape expertise centre, and the regional alliance of sea ports. Together, these actors managed of the station area from 2017 and the Vennen Square from 
to anticipate national funding and start several years ahead of the national dike fortification programme, in order to utilize their momentum and address a combination of societal and spatial challenges in one comprehensive spatial intervention (Bosch 2019). The municipality wanted to counter the negative image and atmosphere of the city centre, which had a reputation of being a rundown place with vacant shops and low-quality public space. Moreover, an island made of chemical waste called the Griesberg, just to the northwest of Delfzijl, had been a worry among and eyesore to nature preservationists for decades (Baptist and de Groot 2012). By joining forces with other parties, the municipality saw an opportunity to finally clean this polluted area right outside the city's coastline.

In 2020, 11 years after the start of the project, the dike fortification and most major sub-projects have been completed. Some parts of the dike strengthening plans were delayed, pushing the subsequent sub-projects further back in time. No heritage experts were involved in the project, neither from local, regional, or national organizations. Citizen participation was not a formal part of the project, but the project manager informed locals through the newspaper. He also held polls in the local newspaper from time to time to see what inhabitants really wanted to see included in the new plan. The respondents stressed the importance of having access to a beach (Veldman 2020).

\section{The quarry of the past}

The Marconi project can be seen as a process in which the past has been framed as a resource that can be re-interpreted and consumed. This process also occurred in Delfzijl, as the Marconi plan deliberately mined the city's quarry of the past for useful objects and narratives. In order to understand this process, we will now sketch a brief outline of this quarry, enabling us to point out how the planners and designers involved in the Marconi project selected and re-interpreted elements from the quarry, representing dominant narratives of the area's past and its material remains. It is almost impossible to include elements of the past that were allowed to fall into oblivion, but we have been able to detect the rather drastic tendency to demolish historic structures in Delfzijl from the early nineteenth century onwards, which now have a dominant presence in the city (Bosch 2019; Veldman 2020).

Delfzijl lies in the intertidal mudflat zone of the Wadden Sea area. Around $4500 \mathrm{BC}$, between $600 \mathrm{BC}$ and $425 \mathrm{AD}$, and from $825 \mathrm{AD}$ onwards, people inhabited this area, living on dwelling mounds or wierden. Each time, these phases of habituation ended due to the sea level rising, after heightening the dwelling mounds was no longer an option. From 900 AD onwards, the area became permanently inhabited and monasteries were founded, from where the area was Christened (Beukema 2009).
A new form of water management emerged in the eleventh and twelfth centuries, when farmers started building dikes to prevent their lands from flooding several times per year, later supported by the wealthy monasteries Bügel (1981). Canals, sluices, and polders were constructed to manage the water in the area in the thirteenth century. A settlement formed around three adjacent sluices (or zijlen) in the river Delf, which would later develop into Delfzijl. However, the people proved unable to tame the powerful sea, as large areas were swallowed by the sea, drastically enlarging the Eems-Dollard sea arm (Beukema 2009). In later centuries, flooding would remain a recurring threat to Delfzijl and the surrounding area.

Due to the strategic importance of its sluices, Delfzijl was fortified and strengthened with bulwarks during the EightyYears War (1555-1648), in which the protestant Dutch fought against Catholic Spanish dominance. From 1594, the area came into the hands of the Dutch protestants, meaning Catholicism, including its monasteries, was evicted from the area.

The Republic of the Seven United Provinces developed into a global trading power in the seventeenth century, when the harbour of Delfzijl was used intensively by the West India Company (Beukema 2009). The trading success of the Dutch led to tensions with competitors from England, ultimately culminating in four Anglo-Dutch wars. Several fleets anchored in Delfzijl after returning from battle in 1665 (under Michiel de Ruyter) and in 1672 (under Arnoud van Overbeek), and Delfzijl's fortifications were strengthened in 1780 to defend the city in case of an attack by the English (Beukema 2009).

In the age of the Batavian Republic (1795-1806), Delfzijl was again an important strategic harbour for the French government in their conflict with the English. Therefore, the city's garrison facilities were expanded in 1799. Under King Louis Napoleon and under the French rule, Delfzijl remained a strategically important harbour for army fleets and the transport of troops and was therefore heavily armed in times of political turmoil, such as Napoleon's Russian Campaign in 1812. When the Dutch government was formed in 1813, Delfzijl was the last fortified city to capitulate after a long siege in 1814 that left the city heavily damaged and poor. After the siege, room was made for a catholic church, a synagogue, and a Jewish school. The city was completely renewed in many places in 1830-1831, with several gates being demolished and the garrison church and water board house being replaced.

In the second half of the nineteenth century, Delfzijl transformed from a fortified garrison city into a harbour city, after the foundation of a school for sailors, a national pilotage service, and the opening of the new Eems channel. After 1876, the fortifications were demolished and the moats were partially filled up to make room for city expansions. The garrison compound was filled up with dense housing. Delfzijl gained importance as a regional harbour, where goods were transferred from sea vessels to inland ships. A new quay and 
harbour for inland ships were developed for this purpose in 1903. Delfzijl was also connected to the national railway network in 1884 and to the telegraph network in 1899. The harbour and related industrial activities were drastically expanded from the 1960s onwards, erasing several villages in the Oosterhoek area from the map De Groot-Van D Meulen CA (1991).

In this period of industrial expansion, the Dutch national government developed serious plans to turn large parts of the Wadden Sea into polder land for agricultural use. These plans prompted fierce demonstrations from ecologists, biologists, and the general public, who treasured the biodiversity of the area. In the 1970s, this saw the first national policies for nature preservation to take shape under progressive Prime Minister Joop den Uyl (Oosterveld 2010), resulting in a Spatial Planning Decree dedicated solely to the Wadden Sea area in 1980 (VRO 1980). Since then, the natural and geological values of the area have been protected in national policy, with inhabited areas being strictly separated from those without human settlements. On the mainland, this meant that the sea dike formed the boundary for these policies Egberts (2019). In those decades, the Wadden Sea and the Dollard area became well protected as National Natural Monuments (Staatsnatuurmonument). The Wadden sea also became a protected area under the Birds Directive of the European Community (1979), the national Nature Protection Law (1998) (LNV 2008), the European Habitats Directive (2003), and Natura 2000 (2007) Oosterveld (2010). Trilateral cooperation between Denmark, Germany, and the Netherlands led to joint decision-making on the banning of large-scale wind parks, but also to the candidacy of the trilateral Wadden Sea region to become a World Heritage Site. In 2009, this title was granted for Germany and the Netherlands, based on the biodiversity and geological values of the area. In 2014, Denmark's Wadden Sea area was added to the listing (UNESCO 2020). For Delfzijl, this has meant that the sea dike that separates and protects the town from the sea is now the border of a nature reserve of international significance.

\section{Heritage selection}

When we analysed the planning documents of Marconi Delfzijl, we made several key observations regarding the ways in which planners and landscape architects deliberately "mined" the quarry of the past for specific narrations, images, and objects that seemed useful to them in the Marconi plan.

What struck the eye straight away is the name of the project, an abbreviation of the Dutch for maritime concepts in sight (Delfzijl, 2009). As such, the name of the project itself suggests a focus on the maritime character of Delfzijl. The central aim is to "repair the maritime character of Delfzijl" (Delfzijl 2009, p. 3). Alongside the use of historic images of Delfzijl's harbour in the central planning document (Delfzijl
2009, see Fig. 4), a nostalgic tone was set. Project leader Jornand Veldman added: "but if you are proud of your town again and of what it used to be, proud of your history again..." (Veldman 2020).

Secondly, it struck us that the sea dike is not considered to be heritage or to belong to a larger heritage landscape. Rather, it is approached as a technical entity and a barrier between the sea and the city (Delfzijl, 2009). Process manager Arjen Bosch said the following about the dike: "it is an artifice, after all. You put a hard structure in the sea again that does not really belong there" (2019). In later stages of the project, the dike itself was regarded and designed as a public space that enables the connection between Delfzijl and the Wadden Sea (Delfzijl, 2013). This demonstrates that, as it is understood by stakeholders, spatial planners, and landscape architects, heritage does not comprise these aspects of the cultural landscape. Instead, the dike fortification project and the underlying decision to adapt to climate change have been embraced as a means to an end. "The idea is to make a virtue of necessity and to use this large investment in such a way that the position of Delfzijl can be strengthened structurally", as the central planning document puts it (Delfzijl, 2009).

A third observation is that the Marconi project seems to legitimize and intensify the function of the dike as a spatial, cultural, and legislative border between what is regarded as cultural landscape and what is perceived as nature. Cultural heritage is projected on and integrated in the new plans for the areas inside the dike, such as the renewal of the historic city centre with eighteenth century scales and street patterns in

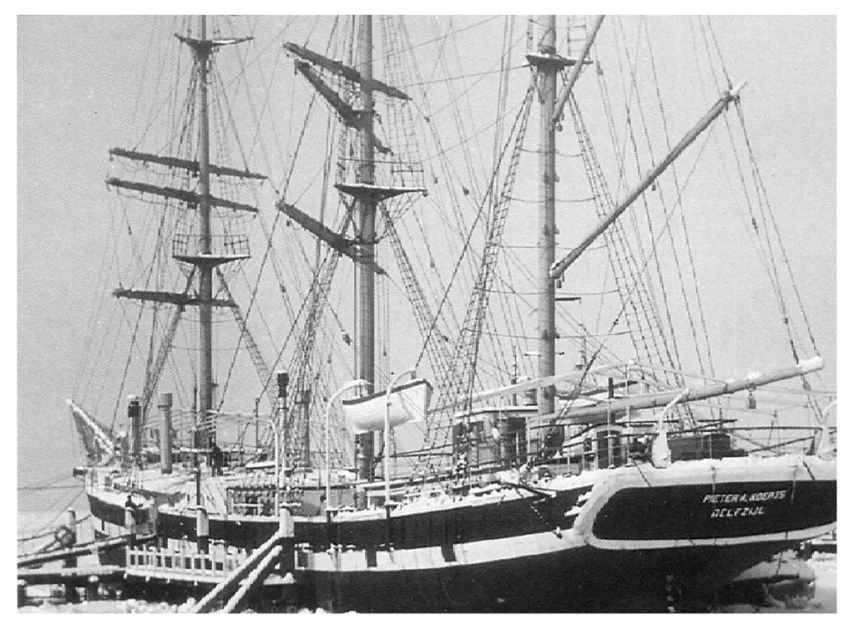

Fig. 4 This three-mast sailing boat figures prominently in the Marconi master plan document from 2009 (p. 3). The historic boat was owned by the municipality of Delfzijl from 1954 to 1964 and was used as a youth hostel. As the maintenance costs rose, the boat was sold and eventually sunk in Bremerhaven due to lack of maintenance. Even though Delfzijl was not able or willing to pay for this historic ship's upkeep decades ago, it still serves as a useful reference to a maritime past in the context of current-day climate adaptation planning. Source: RTV Noord, Drijvende jeugdherberg Delfzijl komt triest aan zijn eind in Duitsland", 9 November 2019 
mind. Hardly any cultural heritage arguments are raised for planning decisions outside the dike. One exception is the preservation of the beach pavilion, spearheaded by locals (Fig. 5), and another, implicit, exception is the use of small dams made with wooden poles and willow branches (rijsdammen) in the experimental new salt marshes on the protective dike (Fig. 6). These techniques were used for centuries to use tidal movement for slow land reclamation by catching in tidal silt on the mainland Wadden coast (Schroor 2018). This can also be said for natural heritage, which is exclusively projected outside the dike, by creating these salt marshes that will largely be closed off for the public to give Wadden flora and migratory birds free range (Delfzijl, 2009, p. 2).

These implicit implementations of long-standing dichotomies between heritage and spatial planning seem so selfevident that they are no longer questioned. In these practices, we recognize what Laurajane Smith calls Authorized Heritage discourses (2006), which legitimize the use of the past in particular ways to support existing power structures. In the case of Delfzijl, the fact that the sea dike is approached as a separation between the cultural and natural world prohibits the experience of the relationship between those worlds. Egberts (2019) argues that this is the case for other areas in the Wadden Sea region as well. Moreover, the designation of the sea dike as the boundary of the Wadden Sea World Heritage Site makes it an artificial barrier in a maritimecultural landscape, in which the sea and land are entangled in a highly dynamic relationship. Others have also argued that this spatial separation between culture within the dikes and nature at sea has negative effects on the holistic management and livability of the Wadden Sea area (Renes 2018; Enemark and Fischer 2018; Döring and Ratter 2018). Despite the integrated character of Marconi and the desire to lessen the barrier function of the sea dike, heritage considerations were hardly and not consciously employed to support this ambition.

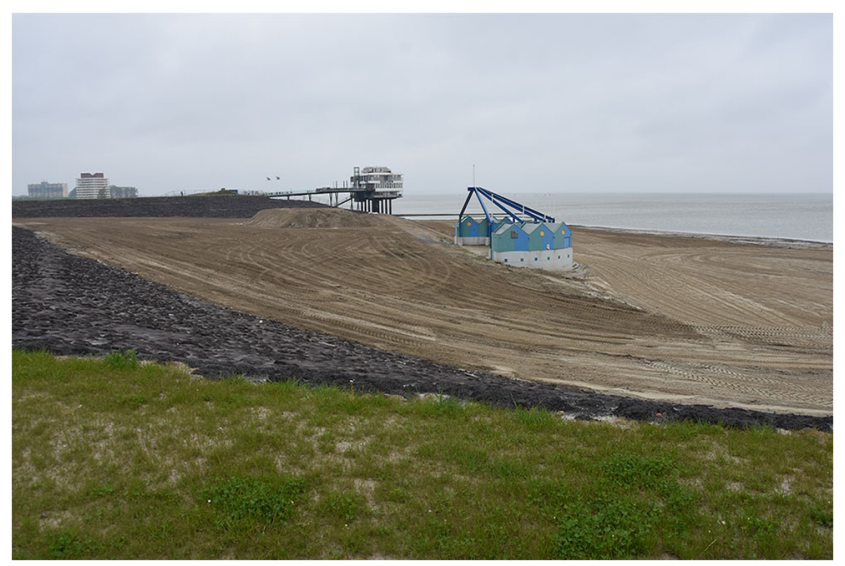

Fig. 5 The bathhouse was preserved during the dike fortification and beach enlargement around it. Image by author, 2019

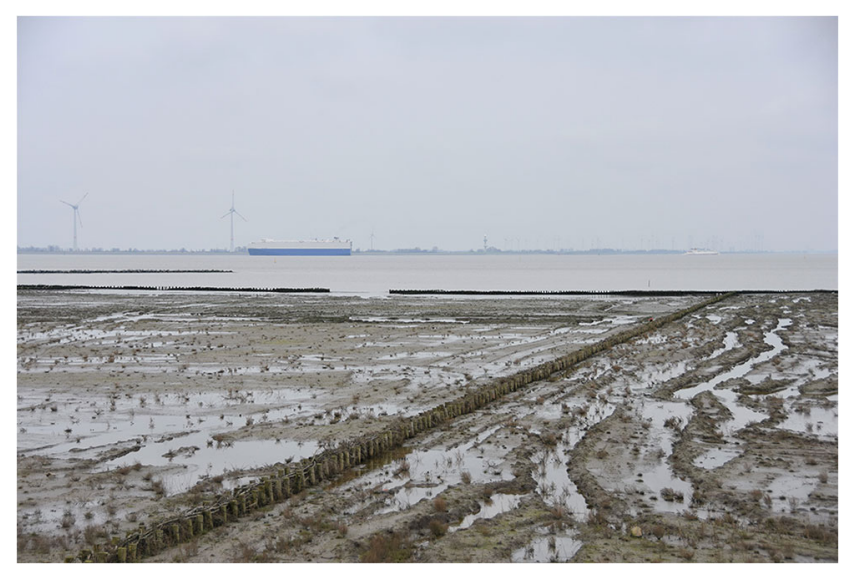

Fig. 6 Historic techniques to catch silt have been used in the new experimental salt marshes, designed by EcoShape

\section{Heritage targeting}

The maritime character of Delfzijl was explicitly chosen as the starting point for the dike fortification project and the suggestion to bring Delfzijl back to the sea met with universal enthusiasm. "Look, Marconi, maritime concepts in sight, it is already in the word concepts, it was mainly about cooperation", as Veldman (2020) states. Based on the planning documents and interviews, we can establish that this cultural heritage theme served several purposes.

Firstly, this joint sentiment appeared to provide a solid basis for bringing the stakeholders together for this large project and many sub-projects (Bosch 2019; Veldman 2020). Secondly, it resonated with inhabitants, who were not structurally consulted or engaged in the planning process but were consulted every now and again in newspaper polls and informed during annual local events. And thirdly, it served as a good strategy to bring the UNESCO World Heritage Site to the attention of the stakeholders. This was done to increase awareness of the opportunities that the World Heritage status could bring with regard to attracting more visitors to the area.

Marconi produced heritage, based on selective interpretations of the past. Now the plan has been completed; however, this heritage lies haphazardly scattered across the plan area and hardly contributes to the narrative of the maritime character of Delfzijl, which the planners aimed to do. In the plans and in public space, we came across old buoys that had been placed back into the city centre and a large concrete bunker, belong to the Atlantic Wall defense line from the Second World War, was left in place on the inside of the raised dike. It is now part of the local maritime and history museum (Fig. 9). Planners and architects also re-interpreted several lost elements of Delfzijl's past. This becomes most visible in a silhouette of the city's former fortifications near the railway station (Fig. 7) and large-scale shopping facilities and apartments that were designed with a small-scale façade with historicizing use of materials and rhythm (Fig. 8). The aim was to 


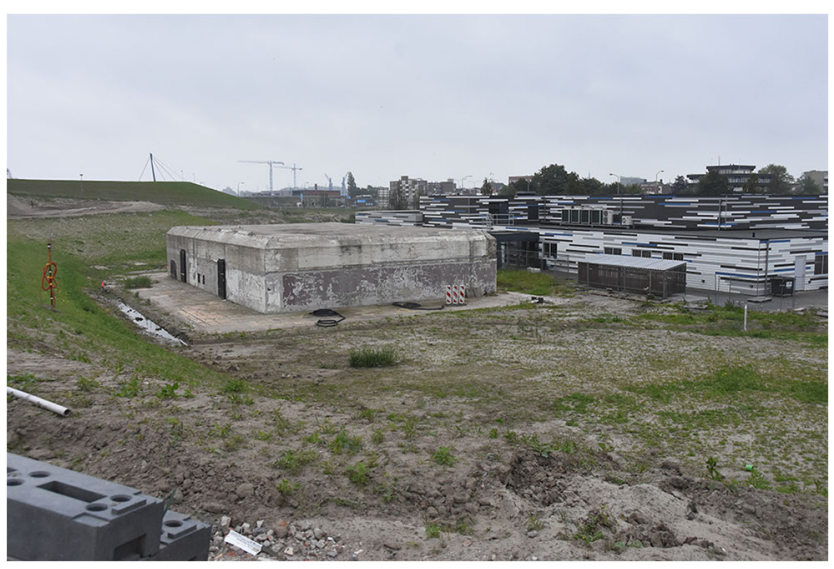

Fig. 9 An Atlantikwall bunker was preserved in the dike fortification project. Due to inhabitants' resistance, the local maritime and historical museum remained in the adjacent building; a former indoor swimming pool. Image by author, 2019

recreate a pleasant atmosphere, which could best be done by employing a smaller scale (Veldman 2020). As such, various sub-projects engage differently and pragmatically with the city's past.

This might be connected to the general opinion that too much had been demolished in Delfzijl over the past two centuries, with most historic buildings having been lost. In some way, Marconi tried to heal these wounds by referring to a general sense of nostalgia without re-using or being able to re-use material remains from the past. However, it must be noted that only specific elements from the past were chosen to be re-used, whereas others were eradicated. During the project, the large modernist Vennenflat and a dilapidated harbour building were demolished to make room for parking and public space (Fig. 9).

Now that the dike reinforcement project in Delfzijl has almost been completed, there are clear elements of reinterpreted heritage to be seen in various places, though they

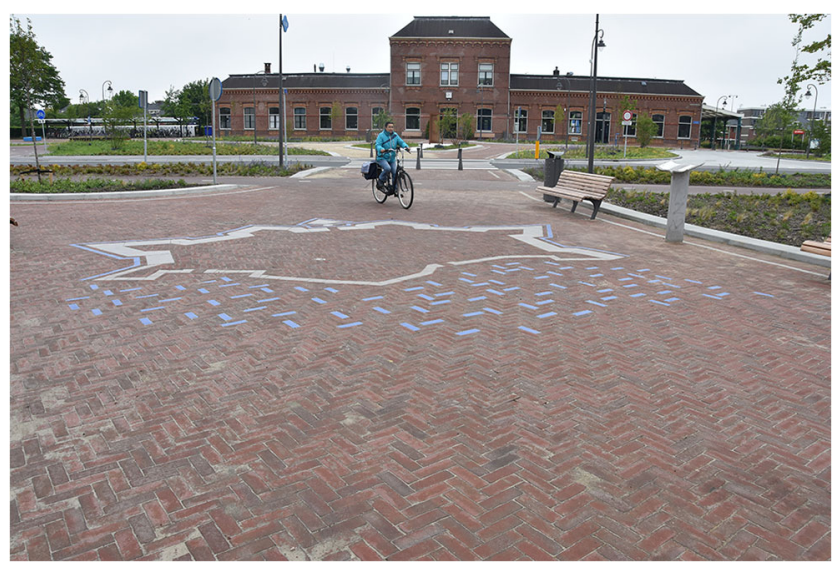

Fig. 7 The new pavement in front of the railway station marks the location of a former fortification structure from the time that Delfzijl was a garrison town. The connections to the sea are depicted by using blue-glazed bricks. Image by author, February 2020

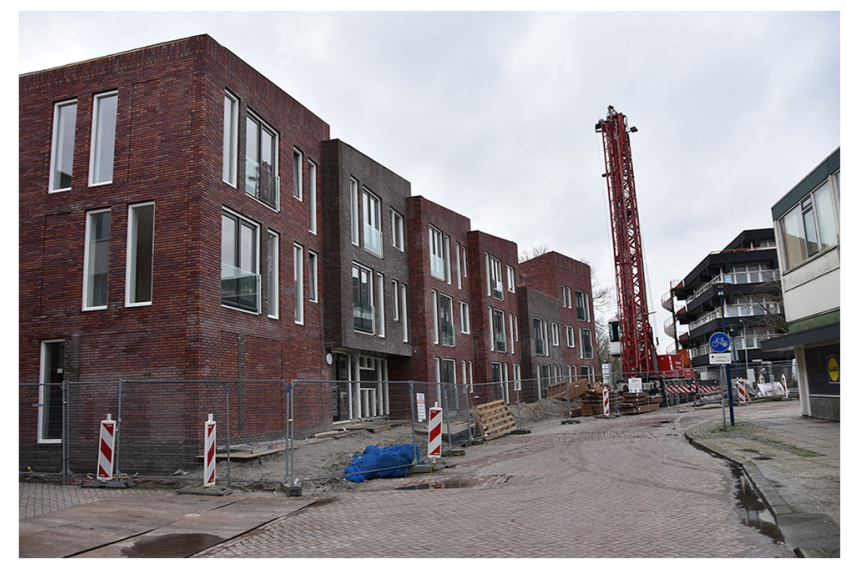

Fig. 8 A new shopping and apartment building has replaced a large, modernist 1970s flat. Its facade creates the impression of a building of a smaller scale. Image by author, February 2020

are fragmented and difficult to "read" for anyone outside the project team. In some places, it is made clear that Delfzijl is a seaside city, but hardly any other unique heritage narratives or qualities are re-interpreted and presented. Consequently, this project has missed opportunities to strengthen the heritage qualities of the town for inhabitants and visitors alike. For an area that is rapidly becoming less populous, these narratives could have been useful for attracting more cultural tourism than it currently does. Research elsewhere in the Dutch Wadden Sea area has proven the potential of cultural heritage for sustainable tourism (Hartman and Sijtsma 2018). On the other hand, a coherent re-interpretation of Delfzijl's past had not been in the municipality's plans in the first place. In the words of project leader Jornand Veldman: "To this day, I cannot tell you what 'maritime' really is, or how to become it" Veldman (2020). Indeed, "the repair of the maritime character of Delfzijl is not an aim in itself, but rather a catalyst for a more vibrant Delfzijl" (Delfzijl 2009, p. 3).

\section{The heritage production model in climate adaptation planning and design}

In this case study, we applied Ashworth and Tunbridge's model of heritage production (Fig. 2) to investigate to what extent it could help us better understand spatial planning and landscape architecture for climate change as heritage practices. The heritage production model was originally conceived for the context of (cultural) world heritage sites but yields relevant observations here, too. The separation of "selection" and "targeting" as two identifiable aspects of heritage practices, in particular, helped us to demarcate clearly what aspects and objects were deliberately re-used from the past and how they were re-used. This enabled us to see clearly that the use of the "maritime" narrative did not result in a well-readable, targeted end result or product, to stay with Ashworth's and Tunbridge's wording. However, the use of the past served the 
processual purpose of bringing stakeholders together and defining a shared agenda for the future of Delfzijl.

In evaluating the usefulness of all aspects of the model in a climate adaptation context, some of the categories of the model are too obviously tied to (cultural) World Heritage Sites to be very relevant here. This mainly applies to the box of "conservation agencies", as no such agencies were involved in the Marconi plan, apart from their very indirect involvement through the management of the Wadden Sea World Heritage Site. They also play a minor role in the construction of Delfzijl's quarry of the past, which is dominated by stories of demolition and industrial expansion rather than heritage preservation. To some extent, the same applies to the "heritage industries" box. One of the aims of the Marconi plan is to increase Delfzijl's appeal for visitors, but by making a larger parking area for campervans and expanding the facilities for recreational boats, Delfzijl has not really created a packaged heritage product for the tourism industry. The fact that Marconi is primarily a climate adaptation project in the first place largely explains this observation. In that sense, the rather industrial choice of wording (products, industries, assembly, etc.) might be more applicable to touristic heritage sites where heritage is "packaged and sold" and less applicable to projects where the basic incentive is to increase the security of the local population and the livability of the area.

\section{Conclusion and discussion}

Our case study shows clearly that the initiators of the Marconi plan have deliberately tried to heal some of the scars left by two centuries of demolition in Delfzijl. They did so by employing a nostalgic narrative of an historic town at the coast, which effectively brought many stakeholders together in a uniquely holistic planning process. In the newly shaped environment, this resulted in the rather fragmented and pragmatic use of hints to a rather general, maritime past. In the process, some less desired physical remains were deliberately demolished, as they were regarded unsuitable for reinterpretation.

The most striking observation regarding the Marconi plan, however, is that the project largely taps into existing heritage narratives that demarcate the sea as a place of nature and the city centre as a place of cultural heritage. This way, the discursive relationships between nodes of meaning, which were constructed in previous heritage practices, are being maintained and reinforced. Ironically, the Marconi plan therefore repeats the mental separation of these two domains, whereas its aim had been to connect and - quite literally—build bridges between the town and the sea. The dike between these two areas was regarded as an infrastructural entity that enables the overall planning process, but was, in itself, not regarded as a heritage structure.

The Marconi plan was initiated as a climate adaptation project that would protect the town from the potentially destructive power of the sea. When we look more closely at the overall rhetoric of the plan, though, this looming danger is nowhere to be found. Rather, the attractiveness of the sea as a place of leisure and recreation is celebrated and facilitated by means of heritage and through planning and design interventions such as beaches, bridges, campervan spaces, and a sea dike as a recreational area. Attentive readers might have noticed the virtual absence of climate change throughout the article. This reflects the rhetoric used in the Marconi plan, which expresses a strong desire to turn negative narratives such as potential flooding into positive ones, such as those of a pleasant, historic city at sea. Comparative analysis of climate adaptation projects could yield insight into whether the Marconi strategy is unique, or if other projects are also pushing disturbing forecasts to the background and instead promoting more attractive and calming narratives for the future, based on a soothing image of the past.

Using Ashworth and Tunbridge's heritage production model allowed us to disentangle several important aspects of spatial planning and landscape architecture for climate adaptation as heritage practices in a structured way. This makes the model a useful tool for understanding the role of heritage in climate change planning beyond the single-case-study level. The model allows researchers to structure and analyse multiple individual cases in a similar way, thereby serving as a solid conceptual resource for drawing relationships and potentially discerning patterns among multiple adaptation projects, even in international contexts.

By applying the model in the context of spatial planning and landscape architecture for climate adaptation, we demonstrate that deliberate choices about heritage are enmeshed in these large-scale planning projects, even if heritage experts or heritage lists have not been consulted or involved. Studying Marconi from a heritage perspective, however, also showed us that the use of heritage can be result-oriented or aimed at the planning process, the latter of which being the case for Marconi. In a sense, this is very much in line with what Holtorf (2018) advocates, namely creative engagements with the past that make communities more resilient for the future. Even though Delfzijl's past has become hardly more readable in the present-day landscape, at least the past served as a useful tool to protect the city from potential flooding and to increase its livability for present and future inhabitants. 
Acknowledgements We would like to thank the editors of the special issue, in particular Cormac Walsh and Martin Döring, for their valuable comments on earlier drafts of this article. We would also like to thank Bert Brouwenstijn for reproducing the figures by Ashworth and Tunbridge (1997) and Marilena Mela for making a map of the study area.

\section{Declarations}

Conflict of interest The authors declare no competing interests.

Open Access This article is licensed under a Creative Commons Attribution 4.0 International License, which permits use, sharing, adaptation, distribution and reproduction in any medium or format, as long as you give appropriate credit to the original author(s) and the source, provide a link to the Creative Commons licence, and indicate if changes were made. The images or other third party material in this article are included in the article's Creative Commons licence, unless indicated otherwise in a credit line to the material. If material is not included in the article's Creative Commons licence and your intended use is not permitted by statutory regulation or exceeds the permitted use, you will need to obtain permission directly from the copyright holder. To view a copy of this licence, visit http://creativecommons.org/licenses/by/4.0/.

\section{References}

Baptist, Martin, and Alma V. de Groot. 2012. Ecologische Bemonstering Griesberg, Delfzijl. In Rapport / Imares Wageningen Ur, C143/12. IJmuiden etc.: IMARES Wageningen UR http://edepot.wur.nl/ 255435 .

Beukema, Hans. 2009. Delfzijl Historiaal: De Geschiedenis Van De Gemeente Delfzijl. Delfzijl: Maritext.

Bosch, Arjen 2019 Stakeholder process manager on behalf of Delfzijl municipality. Beilen, Tuesday 28 May

Bouland, Willemijn 2020 Process manager Kustwerk Katwijk. Online interview 5 June

Braae, Ellen. 2015. Beauty redeemed: recycling post-industrial landscapes. Berlin: Birkhäuser.

Buro Bügel 1981 Van De Dijk Groningen, and Provinciale Planologische Dienst Groningen. Dijkeninventarisatie Provincie Groningen. Groningen: S.n

De Groot-v. D. Meulen, C. A. 1991. Weiwerd, Heveskes, Oterdum: De Verdwenen Dorpen Van De Oosterhoek. Bedum: Profiel.

Delfzijl Municipality. 2009. "Maritieme concepten in beeld." Delfzijl.

Delfzijl Municipality. 2013. "Actieplan Delfzijl Centrum.” Delfzij1.

Dixon Hunt John. 2014. Historical ground: the role of history in contemporary landscape architecture. London: Routledge.

Döring, Martin, and Beate Ratter. 2018. Senses of place in the North Frisian Wadden Sea: local consciousness and knowledge for place-based heritage development. In Waddenland outstanding: history, landscape and cultural heritage of the Wadden Sea Region, ed. Egberts Linde and Schroor Meindert, 293-304. Amsterdam: Amsterdam University Press. https://doi.org/10.2307/j.ctv7xbrmk. 23.

Egberts, Linde. 2015. Chosen legacies: heritage in the construction of regional identity. London: Routledge.

Egberts, Linde. 2019. Moving beyond the hard boundary. Journal of Cultural Heritage Management and Sustainable Development 9 (1): 62-73. https://doi.org/10.1108/JCHMSD-12-2016-0067.
Egberts, Linde, and Dag Hundstad. 2019. Coastal heritage in touristic regional identity narratives: a comparison between the Norwegian region Sørlandet and the Dutch Wadden Sea area. International Journal of Heritage Studies 25 (10): 1073-1087. https://doi.org/ 10.1080/13527258.2019.1570310.

Enemark, Jens, Ludwig Fischer, and Karsten Reise. 2018. Protecting the natural and cultural values of the Wadden Sea coast in the Anthropocene: an urgent call for integration. In Waddenland outstanding: history, landscape and cultural heritage of the Wadden Sea Region, ed. Egberts Linde and Schroor Meindert, 67-80. Amsterdam: Amsterdam University Press. https://doi.org/10.2307/ j.ctv7xbrmk.7.

Fatorić, Sandra, and Erin Seekamp. 2017. Are cultural heritage and resources threatened by climate change? A systematic literature review. Climatic Change 142: 227-254.

Freestone, Robert, Susan Marsden, and Christine Garnaut. 2008. A methodology for assessing the heritage of planned urban environments: an Australian study of national heritage values. International Journal of Heritage Studies 14 (2): 156-175. https://doi.org/10. 1080/13527250701844043.

Garden, Mary-Catherine E. 2006. The heritagescape: looking at landscapes of the past. International Journal of Heritage Studies 12 (5): 394-411. https://doi.org/10.1080/13527250600821621.

Graham, Brian, Greg Ashworth, and John Tunbridge. 2000. A geography of heritage. London: Taylor and Francis.

Hartman, Stefan, and Frans J. Sijtsma. 2018. Sustainable tourism in de the Wadden Sea region: key mechanisms to overcome barriers to sustainability. Leeuwarden: Wadden Academy.

Harvey, David C. 2015. Heritage and scale: settings, boundaries and relations. International Journal of Heritage Studies 21 (6): 577593. https://doi.org/10.1080/13527258.2014.955812.

Harvey, David C., and James A. Perry. 2015. The future of heritage as climates change: loss, adaptation and creativity. Routledge, Taylor \& Francis Group: Key issues in cultural heritage. London.

Holtorf, Cornelius. 2018. Embracing change: how cultural resilience is increased through cultural heritage. World Archaeology 50 (4): 639 650. https://doi.org/10.1080/00438243.2018.1510340.

Holtorf, Cornelius and Graham Fairclough 2013 The new heritage and reshapings of the past', in Reclaiming Archaeology: Beyond the Tropes of Modernity, ed. Alfredo Gonzalez Ruibal London: Routledge 197-210.

Janssen, Joks, Eric Luiten, Hans Renes, and Eva Stegmeijer. 2017. Heritage as sector, factor and vector: conceptualizing the shifting relationship between heritage management and spatial planning. European Planning Studies 25 (9): 1654-1672. https://doi.org/10. 1080/09654313.2017.1329410.

LNV 2008 (Ministery of Agriculture, Nature and Food Security). Natura 2000-gebied Waddenzee. DRZO/2008-001.

Oosterveld, H.R. 2010. Een wereld van verschil: Veertig jaar beleid in het Waddengebied. Leeuwarden: Waddenacademie.

Palmer, C. 2002. Christianity, Englishness and the southern English countryside: a study of the work of H.J. Massingham. Social \& Cultural Geography 3 (1): 26.

Renes, J. 2018. Waddenland outstanding: history, landscape and cultural heritage in the Wadden Sea region. Essay. In The Wadden Sea as a cultural landscape: history, heritage, management. AUP: 45-63.

Rico, T. 2016. Constructing destruction: heritage narratives in tsunami city. Walnut Creek, California: Left Coast Press Critical cultural heritage series 12 .

Riesto, Svava and Anne Tietjen. 2018 Planning with heritage: a critical debate across landscape architecture practice and heritage theory. In: 
Routledge companion to landscape architecture. Edited by Ellen Braae and Henriette Steiner Routledge 240-253

Roymans, Nico, Fokke Gerritsen, Cor Van Der Heijden, Koos Bosma, and Jan Kolen. 2009. Landscape biography as research strategy: the case of the South Netherlands Project. Landscape Research 34 (3): 337-359.

Schroor, M. 2018. Landschapsbiografie van het Waddengebied. Historisch-landschappelijke karakteristieken en hun ontstaan. Amersfoort: Rijksdienst voor het Cultureel Erfgoed and Staatsbosbeheer.

Smith, Laurajane. 2006. Uses of heritage. London: Routledge.

Spirn, Anne Whiston. 1997 The authority of nature: conflict and confusion in landscape architecture. In NATURE AND IDEOLOGY Natural Garden Design in the Twentieth Century edited by Joachim Wolschke-Bulmahn 249-261.
Tunbridge, John E., and Gregory J. Ashworth. Wiley. 1996. Dissonant Heritage: The Management of the Past as a Resource in Conflict. Chichester: Wiley.

UNESCO. 2020. Wadden Sea. https://whc.unesco.org/en/list/1314/ (accessed 22 June 2020).

Veldman, Jornand 2020 Project manager on behalf of Delfzijl municipality. Delfzijl, 27 February

VRO 1980 Ministry of Housing and Spatial Planning Planologische Kernbeslissing Derde Nota Waddenzee. Ministry of Housing and Spatial Planning.

Publisher's note Springer Nature remains neutral with regard to jurisdictional claims in published maps and institutional affiliations. 